\title{
Chapter 4 \\ Organizational Trust, Fear of Job Loss, and TFP Growth: A Sectoral Analysis for the $\mathrm{EU}$
}

\author{
Felix Roth
}

\begin{abstract}
Analyzing the sectoral variance in growth rates of total factor productivity in a European country sample from 1996 to 2006, this contribution detects no significant relationship between organizational trust and TFP growth. Yet, the relationship between fear of job loss and TFP growth seems to be significantly associated, in an inverted U-shaped relationship. This relationship proves to be robust to a range of alterations. The analysis concludes that depending on the specific sector, to enhance productivity it might be beneficial to liberalize or regulate employment relations. When analyzing the non-farm market sectors $\mathrm{C}-\mathrm{K}$, the relationship takes the form of a significant, negative linear relationship.
\end{abstract}

Keywords Organizational trust $\cdot$ Fear of job loss $\cdot$ TFP growth $\cdot$ Sectoral analysis · EU

JEL Classifications D24 $\cdot \mathrm{J} 89 \cdot \mathrm{L} 23 \cdot \mathrm{L} 60 \cdot \mathrm{L} 70 \cdot \mathrm{L} 80 \cdot \mathrm{O} 30 \cdot \mathrm{O} 52 \cdot \mathrm{Z} 13$

\begin{abstract}
Originally published in: Felix Roth. Organizational Trust, Organizational Fear and TFP Growth: A sectoral analysis for the EU. European Commission, 7th Framework Programme, No. 258747, 2013. The Impact of Service Sector Innovation and Internationalisation on Growth and Productivity SERVICEGAP Discussion Paper No. 20.

The author wishes to thank the participants at the INDICSER project during workshops in London (February 2010) and Valencia (April 2011), those at the SERVICEGAP project during workshops in Birmingham (June 2010), Dublin (June 2011), and Mannheim (November 2012), and those at the ZEW research seminar (June 2011) in Mannheim. In addition, the author would like to thank Mary O'Mahony, Jonathan Haskel, Marcel Timmer, Irene Bertschek, and Stanley Siebert. The author is grateful for a grant from the European Commission under the Seventh Framework Programme (FP SSH 2009 1.2.1) for the SERVICEGAP project ("The Impact of Service Sector Innovation and Internationalisation on Growth and Productivity," contract number 214576). The author would also like to thank Paola Trevisan, Anna Thum, and Raf van Gestel for valuable research assistance. Finally, the author would like to thank Greet Vermeylen and Sylvie Jacquet at the European Foundation for the Improvement of Living and Working Conditions (Eurofound) for valuable help concerning the screening of all available datasets produced by Eurofound.
\end{abstract}

\footnotetext{
Felix Roth $(\bowtie)$

Department of Economics, University of Hamburg, Hamburg, Germany

e-mail: felix.roth@uni-hamburg.de
} 


\section{Introduction}

In analyzing the productivity gap between the US and Europe over the period 1995-2006, Timmer et al. (2010, p. 32 and p. 36) and van Ark et al. (2008, pp. 39-41) highlight that the gap largely results from slower growth of total factor productivity (TFP) in European market services, particularly in distributive trade as well as financial and business services. The authors argue that among other factors it will most likely be the missing input of intangible capital that is able to explain the result of slower TFP growth in European market services (Timmer et al., 2010, pp. 259-262; Van Ark et al., 2008, pp. 41-42). Concerning the conceptualization of intangible capital, Corrado et al. $(2005,2009)$ group intangible capital into three categories: 1) software, 2) innovative properties, and 3) economic competencies. The last category, economic competencies, is further subdivided into three indicators: 1) brand names, 2) firm-specific human capital, and 3) organizational capital. Within this wide range of indicators, this contribution concentrates primarily on the concept of organizational capital-more concretely, it analyzes the relationship between organizational trust, fear of job loss, and TFP growth over the period 1996-2006 at the sectoral level within a given sample of 15 European countries and 10 economic sector clusters. In this instance, the manufacturing sectors $(\mathrm{C}-\mathrm{F})$ are differentiated from the service sectors $(\mathrm{G}-\mathrm{K})$, the public sectors (L-N), and the nonfarm business sector (C-K).

\section{Theoretical Links}

\subsection{Organizational Capital and Economic Performance}

Organizational capital is seen by many authors as a key driver of economic performance in industries or individual economic sectors (Lev \& Radhakrishnan, 2005, p. 73; Black \& Lynch, 2005, p. 205; Corrado et al., 2005, p. 29 and p. 33). Van Ark et al. (2008, p. 41), and Timmer et al. (2010, pp. 259-260) conclude that among other intangible capital indicators, a lack of organizational capital might explain slower TFP growth in European market services and thus the productivity gap between the US and Europe. But how can organizational capital best be conceptualized? An initial, suitable working definition of organizational capital is given by Lev and Radhakrishnan (2005, p. 75), who define organizational capital as "an 
agglomeration of technologies" that enables some firms in contrast to others to produce higher output by utilizing more efficiently their given level of physical and human capital. These technologies include organizational processes and design (Lev \& Radhakrishnan, 2005), work design and employee voice (Black \& Lynch, 2005), and corporate management practices (Bloom \& van Reenen, 2007).

Whereas the above-mentioned factors could be classified as formal indicators of organizational capital contributing to economic performance, another strand of the literature from diverse scientific fields (including psychological, organizational, business, management, and economic studies) identifies rather informal indicators of organizational capital as being key to organizational performance. Alongside general factors like organizational climate (Patterson et al., 2004) and employee working conditions (Royuela \& Surinach, 2009), these informal indicators include more specific factors, such as organizational social capital (Nahapiet \& Goshal, 1998; Leana \& van Buren III, 1999, 2000), and those connected to organizational trust $^{1}$ (in some of the literature called workplace trust ${ }^{2}$ or employees' trust ${ }^{3}$ ) and fear of job loss (also identified with job insecurity). ${ }^{4}$

\subsection{Organizational Trust and Economic Performance}

In its conceptualization of organizational trust, this contribution follows Leana and van Buren III (1999, 2000), who identify two types of organizational trust as being particularly important to the competitiveness of an organization and thus its economic performance: 1) employees' trust among colleagues and 2) employees' trust towards their superiors/bosses. ${ }^{5}$ But how does employees' trust affect economic performance? The argumentation presented below sheds light on this question without being caught up in the positive trust bias that is common in this field. ${ }^{6}$ Leana and van Buren (2000, pp. 221-25) identify three main factors explaining how employees' trust fosters the competitiveness of an organization. If trust exists, 1) employees are more committed to their organizations than to the particular

\footnotetext{
${ }^{1}$ On organizational trust, see among others Mayer et al. (1995), Dirks and Ferrin (2001), Dirks and Skarlicki (2004), Harisalo and Stenvall (2004) and Gargiulo and Ertug (2006).

${ }^{2}$ Concerning workplace trust, see Heliwell (2006), Heliwell et al. (2009) and Heliwell and Huang (2011).

${ }^{3}$ With regard to employees' trust, see Leana and van Buren III $(1999,2000)$ and on workers' trust, see Schotter (1996).

${ }^{4}$ On fear of job loss, see Blanchflower (1991), Brockner et al. (1992), Probst (2002), Sverke et al. (2002), Probst et al. (2007), Staufenbiel and König (2010).

${ }^{5}$ On the importance of trust in leaders, see also Dirks and Skarlicki (2004).

${ }^{6}$ Two books by prominent academics from the discipline of political science, Trust by Francis Fukuyama (1996) and Bowling alone by Robert Putnam (2000), are biased towards the positive effects of trust. Both books tend to neglect the "dark side of trust" (Gargiulo and Ertug, 2006).
} 
work they do, 2) the goal of creating a more flexible work organization will be easier to achieve, and 3) collective action will be more easily managed within the firm. According to the authors, all three factors add to the competitiveness of an organization.

A similar but more specified discussion is given by Gargiulo and Ertug (2006) on the "dark side of trust", in which the authors identify a theoretical curvilinear relationship between trust and economic performance. Summarizing the literature on the consequences of trust, the authors point to three theoretical channels through which trust might be beneficial for economic performance (p. 170). First, trust is related to lower levels of monitoring, vigilance, and safeguards concerning the actions of the trusted party. This argument is in accordance with Knack and Keefer (1997) and Whiteley (2000), who stress among other things that an employer's monitoring costs are lower in high-trust societies. Second, trust is related to higher levels of commitment concerning the interaction with the trusted party. Third, trust is related to an enlargement of the scale of the exchange between parties. According to the authors, this will then lead to positive economic performance by 1) lowering information processing costs, 2) increasing satisfaction, and 3) reducing uncertainty. In the context of employees' trust towards colleagues/bosses, the second and third arguments are more important than the first, as the first argument would imply the employer's trust of the employee.

Interestingly, alongside these positive outcomes, the authors also identify the negative effects of excessive levels of trust on economic performance (growth): 1) blind faith, 2) complacency, and 3) unnecessary obligations. For a start, excessive trust can produce blind faith, leading to a reduction of monitoring below an optimal threshold, thereby increasing the risk of malfeasance. Furthermore, excessive trust can turn commitment into complacency, which may prevent rapid intervention in declining performance. This argument is in accordance with Bidault and Castello (2009), who assert that when there is a very high level of trust, actors might become too complaisant, leading to diminished levels of task-oriented conflicts and thus lower effectiveness (p. 267). In this instance, Hardin (2006) mentions the potential of blocking social capital (p. 94). Dirks and Ferrin (2001) discuss empirical evidence showing that positive attitudes, such as satisfaction, are not robustly linked to work performance (p. 455). Finally, excessive trust can lead to a swift enhancement of a relationship beyond the optimal level, thereby creating unneeded obligations that act as constraints on the interaction.

\subsection{Fear of Job Loss and Economic Performance}

The above-derived theoretical, curvilinear relationship between organizational trust and growth and the explicit reference to the paradigm of excessive trust already points towards the potential importance of an opposite ${ }^{7}$ but distinct

\footnotetext{
${ }^{7}$ According to theoretical (Ashford et al., 1989, p. 808) and empirical studies (Sverke et al., 2002, p. 253), the concept of trust and fear of losing one's job are negatively related to one another.
} 
concept from trust, that of fear, ${ }^{8}$ for explaining economic performance. To conceptualize fear this contribution uses a prominent concept of fear, namely employees' fear of losing their jobs (for a definition see De Witte, 2005, p. 1; Sverke et al., 2002, p. 243; and Greenhalg \& Rosenblatt, 2010, pp. 9-10). ${ }^{9}$ But how is employees' fear of losing their jobs related to economic performance? Research from the disciplines of psychology and business studies depicts a curvilinear relationship between job insecurity and economic performance. In this context, the popular management literature points out that the relationship between stress (being induced by, among other phenomena, job insecurity) and economic performance takes an inverted U shape (Marks, 2003, p. 42). A similar argument from the academic literature, directly related to job insecurity, is made by Brockner et al. (1992). The assumption of a curvilinear relationship seems to be well embedded in the literature, which puts forward mixed theoretical arguments highlighting both the positive and negative effect of unemployment fears on economic performance.

Concerning the positive relationship, some scholars stress that job insecurity creates a cognitive awareness on the part of employees that will consequently increase their performance (Probst et al., 2007). In addition, heightened perceptions of job insecurity may lead employees to engage in less counterproductive work behavior out of the "fear of termination and the associated financial ramifications with potential job loss" (Probst et al., 2007, p. 483). Staufenbiel and König (2010) argue that fear of losing one's job might motivate employees to work harder in order to safeguard against that loss (p. 103). Another argument is given in the economic literature by Blanchflower (1991), specifically, that fear of unemployment among employees depresses wages significantly, thereby granting the hiring organization a comparative advantage over its competitors.

Concerning the negative relationship, Sverke et al. (2002) conclude that job insecurity lowers economic performance because less secure employees are 1) less involved with the organization and 2) have incentives to withdraw from the organization. Probst et al. (2007) suggest that job insecurity might influence productivity and performance negatively because of a drain of the working memory resources owing to anxiety. Staufenbiel and König (2010) contend that job insecurity produces stress, which in turn negatively affects an employee's organizational commitment (p. 102). Renzl (2008) holds that fear in the workplace leads to a disruption of knowledge sharing, which is of crucial importance to the innovativeness and competitiveness of a firm.

\footnotetext{
${ }^{8}$ Concerning the generalized paradigm of fear, classical sociological thinking has long held that fear is one of the main driving forces behind the evolution of advanced societies and economic performance (see Elias, 1980, pp. 447-51; Marcuse, 1998).

${ }^{9}$ The fear of losing one's job is a more specialized conceptualization than, for example, the organizational climate of fear (Ashkanasy \& Nicholson, 2003).
} 
The foregoing discussion clarifies that, similar to the theoretical arguments on organizational trust, fear of job loss and economic performance are related in a curvilinear manner.

\section{Model Specification, Research Design, and Data}

\subsection{Model Specification}

Following Nicoletti and Scarpetta (2003) and McMorrow et al. (2010), who use a neo-Schumpeterian growth model, the baseline specification takes the following form:

$$
\begin{aligned}
\widehat{\mathrm{TFP}}_{i, j, t}= & \beta_{0}+\beta_{1} \widehat{\mathrm{TFP}}_{L, j, t}+\beta_{2}\left[\ln \left(\mathrm{TFP}_{i, j, t-1}\right)-\ln \left(\mathrm{TFP}_{L, j, t-1}\right)\right] \\
& +\beta_{3} \mathrm{OTF}_{i, j, t}+\beta_{4}\left(\mathrm{OTF}_{i, j, t}\right)^{2}+\beta_{5} X_{i, j, t}+\gamma_{i}+\alpha_{j}+\varepsilon_{i, j, t},
\end{aligned}
$$

where the sign " $\wedge$ " represents the growth rates of the depicted variables; $\widehat{\mathrm{TFP}}_{i, j, t}$ is the average TFP growth in country $i$ and sector $j$ for the 11-year period 1996-2006; $\widehat{\mathrm{TFP}}_{L, j, t}$ represents TFP growth at the frontier economy $L$ and is supposed to capture the degree to which countries have to do analogous innovation activity as lead countries or acquire potential knowledge spillovers; $\ln \left(\mathrm{TFP}_{i, j, t-1}\right)-\ln \left(\mathrm{TFP}_{L, j, t-1}\right)$ represents the productivity gap between a country and the frontier in order to proxy the room for adoption of technologies from the frontier; $\mathrm{OTF}_{i, j, t}$ and $\left(\mathrm{OTF}_{i, j, t}\right)^{2}$ represent the level and the squared level respectively of organizational trust and fear of job loss in country $i$, sector $j$ at time $t^{10} ; X_{i, j, t}$ is a vector of supplementary explanatory variables containing policy and control variables in country $i$, sector $j$ at time $t^{11} ; \gamma_{i}$ and $\alpha_{j}$ represent dummy variables for country $i$ and sector $j$; the residual $\varepsilon_{i, j, t}$ is, as always, assumed to follow a normal distribution where the mean equals zero and a constant standard variance $\sigma_{\varepsilon}^{2}$. $\beta_{0}$ depicts a constant term.

\footnotetext{
${ }^{10}$ For pragmatic reasons it is assumed that organizational trust and fear of job loss remain stable over time. This assumption was necessary to be able to utilize an organizational trust and fear of job loss indicator from 2005 as an explanatory variable for TFP growth from 1996 to 2006. In this instance, Blanchflower and Oswald (1999) find out, when analyzing the trend in job insecurity levels in the US for the period 1977-1998, that job insecurity remains stable. Yet, when comparing the 2005 European Working Conditions Survey (EWCS) (Eurofound, 2005) with the 2010 EWCS (Eurofound, 2010a) data from the INDICSER project (Saam et al., 2011), the fear values differ significantly, particularly in sectors that have been strongly exposed to the economic crisis, such as construction. This finding is also confirmed by Eurofound (2010b, p. 2). Still, the question arises of whether a comparison between these two periods makes a valid counter case, as between 2005 and 2010 nothing less than the worst financial and economic crisis since the 1930s hit most advanced economies around the world.

${ }^{11}$ The control and policy variables have been constructed as averages from 1996 to 2006.
} 


\subsection{Research Design}

The dependent variable is the average TFP growth from 1996 to 2006 in sector $j$ and country $i$. The country sample consists of 15 European countries: Austria, Belgium, the Czech Republic, Denmark, Finland, France, Germany, Hungary, Ireland, Italy, Portugal, Slovenia, Spain, Sweden, and the UK. Of these 15 countries, 12 are from the EU-15 and 3 are transition countries. Overall, 10 sectors (A-B, CtD, F, G, H, I, J, $\mathrm{K}, \mathrm{L}, \mathrm{MtN})$ are included in the analysis. ${ }^{12}$ Following the INDICSER ${ }^{13}$ methodology, only sectoral cells with more than 30 observations were utilized (Saam et al., 2011). Given this limitation, with 10 sectors and 15 countries, it was possible overall to retrieve 103 observations for organizational trust and 100 observations for fear of job loss as depicted in Table 4.1 (in Sect. 4) and Table 4.A1 (in the Appendix).

\subsection{Data}

Following the approach of the INDICSER project (Saam et al., 2011), data on organizational trust and fear of job loss were taken from the European Working Conditions Survey (EWCS) conducted on behalf of the European Foundation for the Improvement of Living and Working Conditions (Eurofound), as it is the only publicly available dataset that enables employees' attitudes and working conditions to be matched with specific economic sectors in a larger European country sample. ${ }^{14,15}$ More concretely, data were taken from the fourth wave of the EWCS

\footnotetext{
${ }^{12}$ The empirical design of the paper has been constructed around the built-in "NACE11-variable", which is given in the fourth wave of the EWCS (Eurofound, 2005). For reasons that seem to be arise from an erroneous coding by Eurofound, the NACE11 variable has included sectors O-Q in the missing category. This error should be corrected by the responsible persons at Eurofound. Being based on the output of the NACE11 variable, the econometric analysis of this paper thus focuses solely on sectors AtN. In contrast to this paper, the INDICSER project (Saam et al., 2011) also depicts data on sectors O-Q by retrieving data from a variable within the fourth EWCS, which provides information at a more disaggregated level than the 1-digit NACE classification. Sector E had to be dropped because the cells had fewer than 30 observations in all 15 countries.

${ }^{13}$ The INDICSER ("Indicators for evaluating international performance in service sectors") project is funded by the European Commission under its Seventh Framework Program (https://cordis.europa. eu/project/id/244709/de).

${ }^{14}$ According to Eurofound (2007) the statistical population of the EWCS includes all persons aged 15 or older whose usual place of residence is in the territory across 31 European countries and who are in employment during the reference period. A person is considered in employment if he or she did any work for pay or profit during the reference week for at least 1 hour. The EWCS draws a representative sample by using multistage sampling; thus, in the first stage, population sampling units were selected using stratified random sampling. The target number of interviews was 1,000 in 14 of the 15 countries in the sample, with the exception being Slovenia, for which the target was 600 interviews.

${ }^{15}$ Although other data sources, such as the European Social Survey, have recently started to collect data on the sectoral structure, these surveys do not include an equally rich range of survey questions concerning working conditions.
} 
(Eurofound, 2005) because it was the first to include information on both of the relevant items: organizational trust and fear of job loss.

To adequately measure the concept of employees ' organizational trust and fear of job loss, the raw population of the EWCS 2005 was filtered by the following criteria: first, self-employed persons were dropped. Second, to analyze a sample of employees who follow a regular work-engagement week, only those employees were kept who worked at least 8 hours but less than 84 hours a week. ${ }^{16}$ Third, managers with supervisory tasks were dropped. Fourth, employees who worked alone (without any other colleagues) were eliminated from the survey.

As direct measures of trust have not been included in the EWCS for ethical reasons, ${ }^{17}$ a trust proxy had to be devised. This proxy is based on the question of whether an employee can get assistance from his or her colleagues and/or boss. ${ }^{18}$ The survey item thus reads as follows: "For each of the following statements, please select the response which best describes your work situation. You can get assistance from colleagues if you ask for it. You can get assistance from your superiors/boss if you ask for it." The responses are based on a Likert scale, with the five answer categories being "almost always," "often," "sometimes," "rarely," "almost never," and "don't know" or "refusal." Following the INDICSER methodological approach (Saam et al., 2011), net measures have been formed by adding the categories "almost always" and "often" and subtracting them from the sum of the two categories "rarely" and "almost never." To measure fear of job loss, there is a question in line with the given literature in the field (Sverke et al., 2002, p. 243): "How much do you agree or disagree with the following statements describing some aspects of your job? I might lose my job in the next 6 months." This survey item also uses a Likert scale, with the five responses being "strongly agree," "agree," "neither agree nor disagree," "disagree," "strongly disagree," "don't know," and "refuse to answer." In accordance with organizational trust, a net fear of job loss variable is calculated by adding the responses "strongly agree" and "agree" and subtracting the sum of those who "strongly disagree" and "disagree."

\footnotetext{
${ }^{16}$ It might theoretically be that, for example, employees who undertake shifts work more than 84 hours. To control for any potential outliers however the author believes that it is valid to exclude any work arrangements of less than 8 hours (or one working day) or more than 84 hours.

${ }^{17}$ In an e-mail communication with the author, an expert at Eurofound noted that the items on trust in one's colleagues and boss are not included in the EWCS on the grounds that they "are very difficult to handle and are easily abused." An adequate survey item for measuring trust, such as "[e] valuate how well or poorly the following descriptions apply to your own workplace: very well, rather well, rather poorly or very poorly... [t] he relationships between the workers and the management are open and based on trust," has been used by Eurofound only in the Finnish Quality of Life Survey.

${ }^{18}$ An expert from Eurofound confirmed that Eurofound itself proxies an item like trust in colleagues and the boss through the above-stated proxy on support from colleagues and the boss. Although this item seems to be more strongly connected to the concept of organizational social capital than organizational trust, to the author's knowledge it is the best publically available proxy for organizational trust.
} 
Other data have been gathered from the following sources:

- Sectoral TFP growth data were retrieved from the EUKLEMS ${ }^{19}$ database. For the dependent variable, the average annual growth rate over the period 1996-2006 was calculated. TFP growth for the aggregated sectors $\mathrm{CtD}$ and $\mathrm{MtN}$ were calculated following formulas from Timmer et al. (2007, pp. 14-16).

- Sectoral TFP-level data were taken from the GGDC Productivity Level Database (Inklaar \& Timmer, 2008). Categories CtD and MtN had to be combined according to the formula in Inklaar and Timmer (2008, pp. 36-38). ${ }^{20}$ Being based on 1997 PPP and the US as a benchmark, the data have been recalculated for the base year 1995 and using Germany as the benchmark.

- The intangible capital variable for sectoral firm-specific human capital and a sectoral indicator for employment protection legislation were taken from the INDICSER (2013) project. $^{21}$

- Sectoral data on the size of firms and type of working contract for the instrumental variable estimation were taken from the fourth wave of the EWCS (Eurofound, 2005).

- Sectoral data on $R \& D$ intensity and product market regulation were taken from the OECD.

- The data for the micro-analysis were taken from the fourth wave of the EWCS (Eurofound, 2005).

\section{Descriptive Statistics}

Table 4.1 shows all 100 aggregated values (subdivided into 15 countries and 10 sectors) of the fear of job loss that are used in the econometric analysis of this contribution. With a value of $-95.1 \%$, Austrian employees who work in the public administration and defense sector (L) have the lowest fear of job loss, whereas Czech employees who work in the construction sector $(F)$ have the highest fear of job loss, with a value of $30.4 \%$. As can be seen from Table 4 .A1, with a mean value of $-55 \%$ and a standard deviation of $25 \%$, on average only a minority of employees are afraid of losing their jobs.

The sectors with the highest fear of job loss are 1) agriculture and fisheries (AtB) at $-16.7 \%, 2$ ) hotels and restaurants $(\mathrm{H})$ at $-33 \%$ (with $-39.6 \%$ being the highest value in the EU-15 country sample), and 3 ) construction $(\mathrm{F})$ at $-40.6 \%$. The sectors

\footnotetext{
${ }^{19}$ EUKLEMS refers to the research project "Productivity in the European Union: A Comparative Industry Approach" and involves EU-level analysis of capital (K), labor (L), energy (E), materials $(\mathrm{M})$, and service (S) inputs. The data can be downloaded from the EUKLEMS website (http://www. euklems.net/).

${ }^{20}$ The author wishes to thank Robert Inklaar for providing the ex-ante capital compensation data required to perform the valid calculation to combine sectors $\mathrm{C}$ with $\mathrm{D}$ and sectors $\mathrm{M}$ with $\mathrm{N}$.

${ }^{21}$ The author is grateful to Anna Rinkow for providing the data.
} 


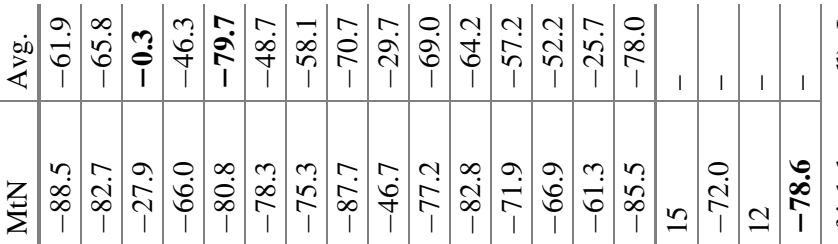

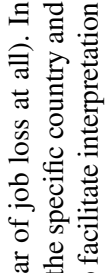

- n 0 n

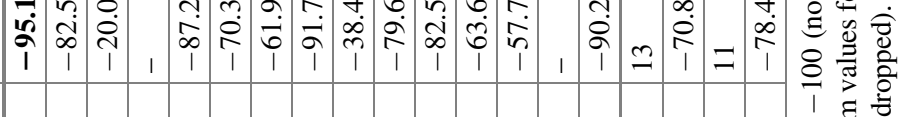

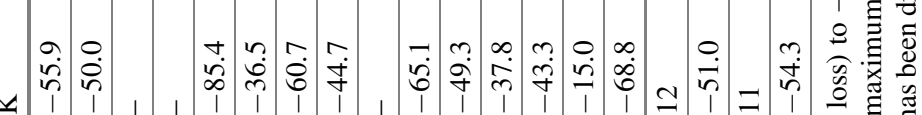

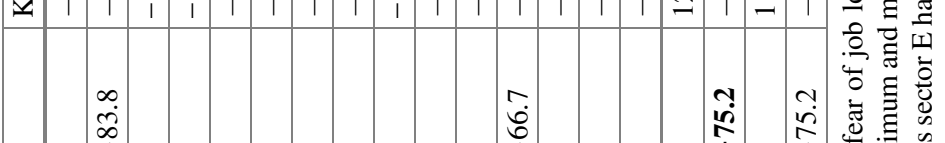

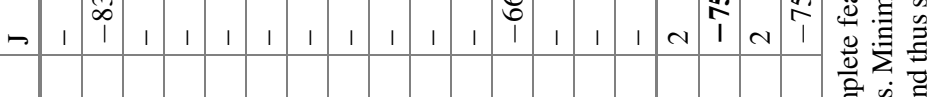

官审

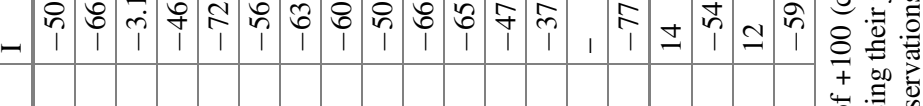

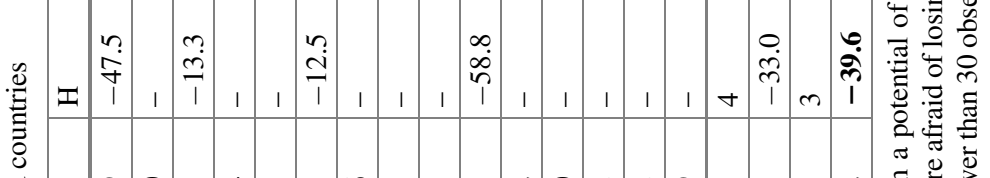

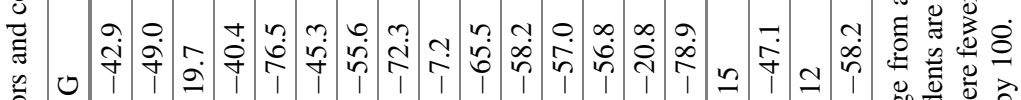

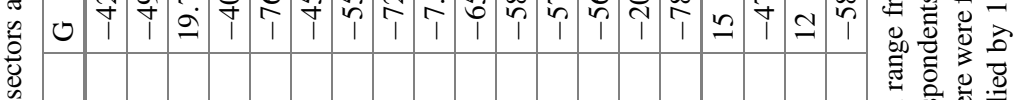

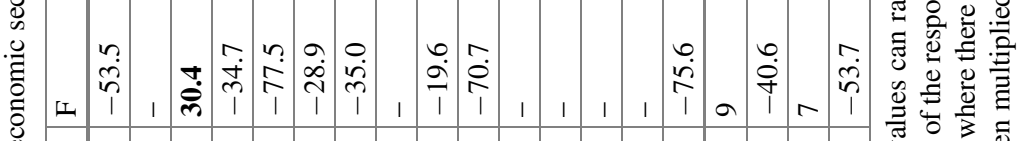

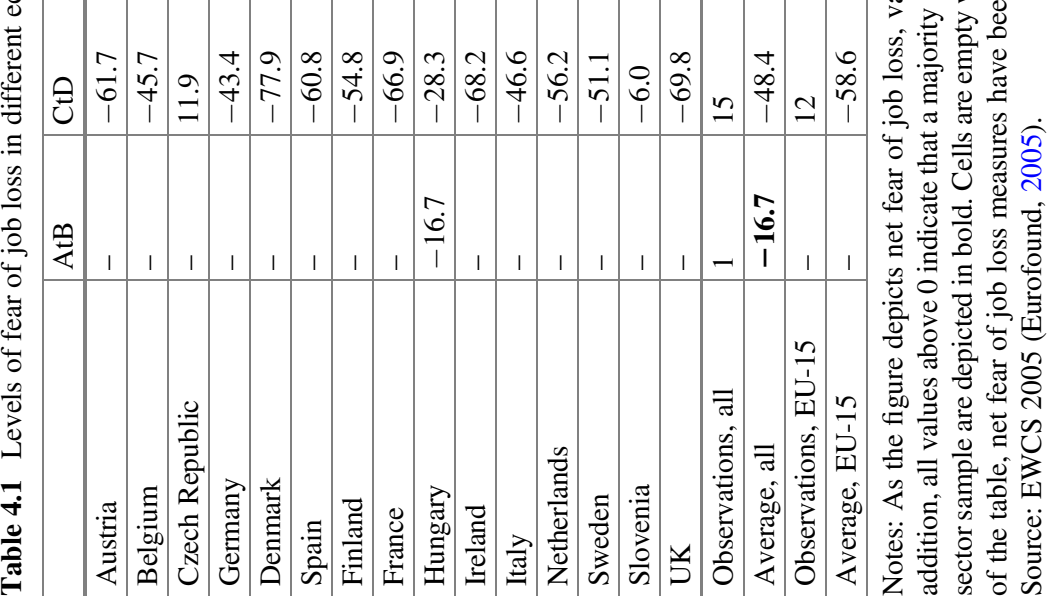


with the lowest fear of job loss are financial intermediation $(\mathrm{J})$ at $-75.2 \%$, education and health (MtN) at $-72.0 \%$ (with $-78.6 \%$ being the lowest value in the EU-15 country sample), and public administration and defense (L) at $-70.8 \%$. When differentiating the non-agricultural market sectors $(\mathrm{CtK})$ from the public sectors $(\mathrm{LtN})$, with the exception of sector $\mathrm{J}$, one finds overall lower levels of job insecurity in the public sector.

When analyzing the average level of fear of job loss from a country perspective, the distribution of fear of job loss is more pronounced compared with the sectoral analysis $(-16 \%$ to $-75.2 \%)$. It ranges from $-0.3 \%$ in the Czech Republic to $-79.7 \%$ in Denmark. Most notably, there exists a significant difference between fear of job loss levels in the three new member states, the Czech Republic, Hungary, and Slovenia (with levels of $-0.3 \%,-29.7 \%$, and $-25.7 \%$, respectively) and the other EU-15 countries (which range in values from around $-50 \%$ to $-80 \%$ ). The only exceptions among the EU-15 countries are Germany and Spain, with an average fear of job loss level of $-46.3 \%$ and $-48.7 \%$, respectively, among employees. ${ }^{22}$ Workers in similar large economies, such as France, the UK, and Italy, have markedly lower levels of fear of job loss, with $-70.7 \%,-78.0 \%$, and $-64.2 \%$, respectively.

In contrast to fear of job loss, which was depicted for all 100 individual observations, Fig. 4.1 shows the net levels of the proxies for trust in colleagues and the boss within the sectoral and country aggregations, while Table 4.A1 shows the summary statistics of net trust in colleagues and the boss. Figure 4.1 reveals that in the transport and communication sector (I), employees' trust in colleagues ranges from $7 \%$ in France to $96 \%$ in Denmark. With a mean value of $69 \%$ and a standard deviation of $19 \%$, levels of net trust in colleagues are in general relatively high and quite evenly distributed around the mean. As depicted in Fig. 4.1, from a sectoral point of view (left side of Fig. 4.1), net trust in colleagues varies from $54 \%$ in the transport and communication sector to $78 \%$ in the financial intermediation sector $(\mathrm{J})$. The picture looks somewhat more differentiated when analyzing net trust in colleagues from a country standpoint. France and Italy, with values of 33\% and 39\%, respectively, have significantly lower levels of net trust in colleagues than the other European countries and the mean of $69 \%$.

Concerning net trust in the boss, the mean value of $52 \%$ is $17 \%$ points lower than net trust in colleagues. In addition, the variation is more pronounced, with trust ranging from $-11 \%$ in the Italian education and health sector $(\mathrm{MtN})$ to $83 \%$ in the Irish wholesale and retail sector $(\mathrm{G})$ and a standard deviation of 0.23 compared with 0.19 . Concerning sectors, it is quite evenly distributed, ranging from $41 \%$ in transportation and communication (I) to $65 \%$ in financial intermediation (J). Looking at individual countries, a startling finding can be detected. Although net trust is relatively evenly distributed among 13 EU countries, Italy and France are clearly outliers. On average net trust in the boss in France is only $2.8 \%$ and in Italy it is only $4.3 \%$. This is an astonishing difference compared with the high levels in Sweden (59\%) and Denmark (77\%), for example, and a mean of 52\%.

\footnotetext{
${ }^{22}$ It has to be pointed out, however, that data for sector L in Germany is missing. As the values for sector $\mathrm{L}$ are on average higher than in other sectors, this fact partially contributes to a lower average value in Germany.
} 


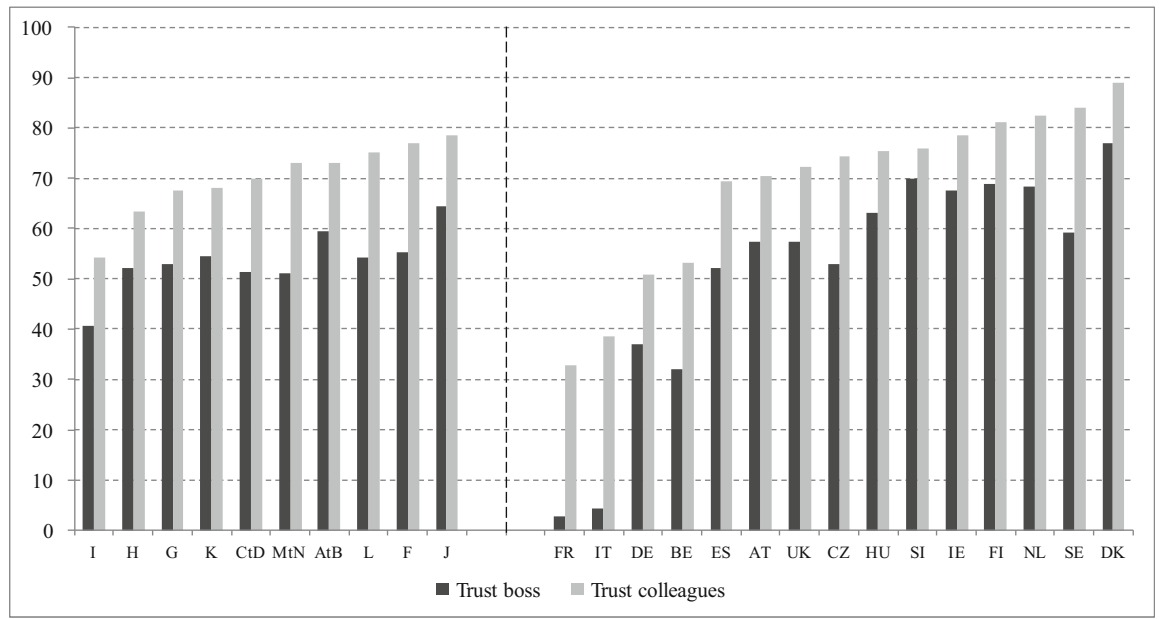

Fig. 4.1 Organizational trust within the different economic sectors and countries Notes: As the figure depicts net trust, values can range from a potential +100 (complete trust) to -100 (complete mistrust). In addition, all values above 0 indicate that a majority of the respondents have trust. The left-hand side of the figure shows the variation by sector. The right-hand side of the figure shows the variation by country.

Source: EWCS 2005 (Eurofound, 2005).

Figure 4.2 shows a partial regression plot between fear of job loss and TFP growth, which reveals the regression results from regression 4 in Table 4.2 (see Sect. 5). When controlling for an economic sector dummy variable in an EU-27 country sample (including the 15 countries under study), the significant curvilinear relationship between fear of job loss and TFP growth is strongly driven by the three transition countries, the Czech Republic, Slovenia, and Hungary. ${ }^{23}$ In the Czech Republic, in particular, high levels of fear of job loss in almost all sectors are associated with low levels of TFP growth.

Figure 4.3 shows a partial regression plot between fear of job loss and TFP growth based on regression 6 in Table 4.2. When analyzing an EU-15 country sample without the Czech Republic, Slovenia, and Hungary and controlling for country effects but not for sectoral effects (in order to fully attribute the full sectoral variance), a significant curvilinear relationship between fear of job loss and TFP growth is detected. Specific sectors that exhibit levels of fear of job loss that are too low and too high with respect to TFP growth rates are identified by country and sector in Fig. 4.3. ${ }^{24}$ Those exhibiting fear of job loss levels that are too low are public administration (L) in Austria, Spain, and France, education and health (MtN) in Austria and Spain, and financial intermediation (J) in Belgium. Sectors exhibiting

\footnotetext{
${ }^{23}$ As depicted in regression 3 in Table 4.2, this relationship turns out to be insignificant when controlling for country effects.

${ }^{24}$ The calculation is based on the distance of these cases to the mean. If the distance is larger than one standard deviation, they are displayed in Fig. 4.3 with the country and sector identification.
} 


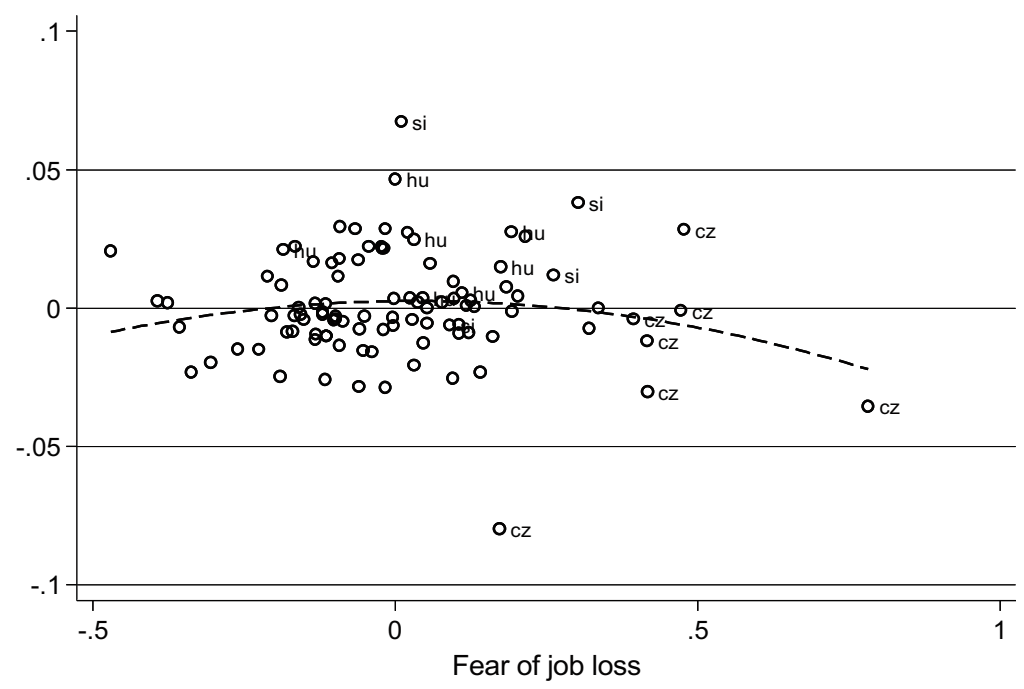

Fig. 4.2 Partial regression plot between fear of job loss and TFP growth-all countries Notes: For country abbreviations, $\mathrm{cz}=$ Czech Republic; $\mathrm{si}=$ Slovenia; hu $=$ Hungary.

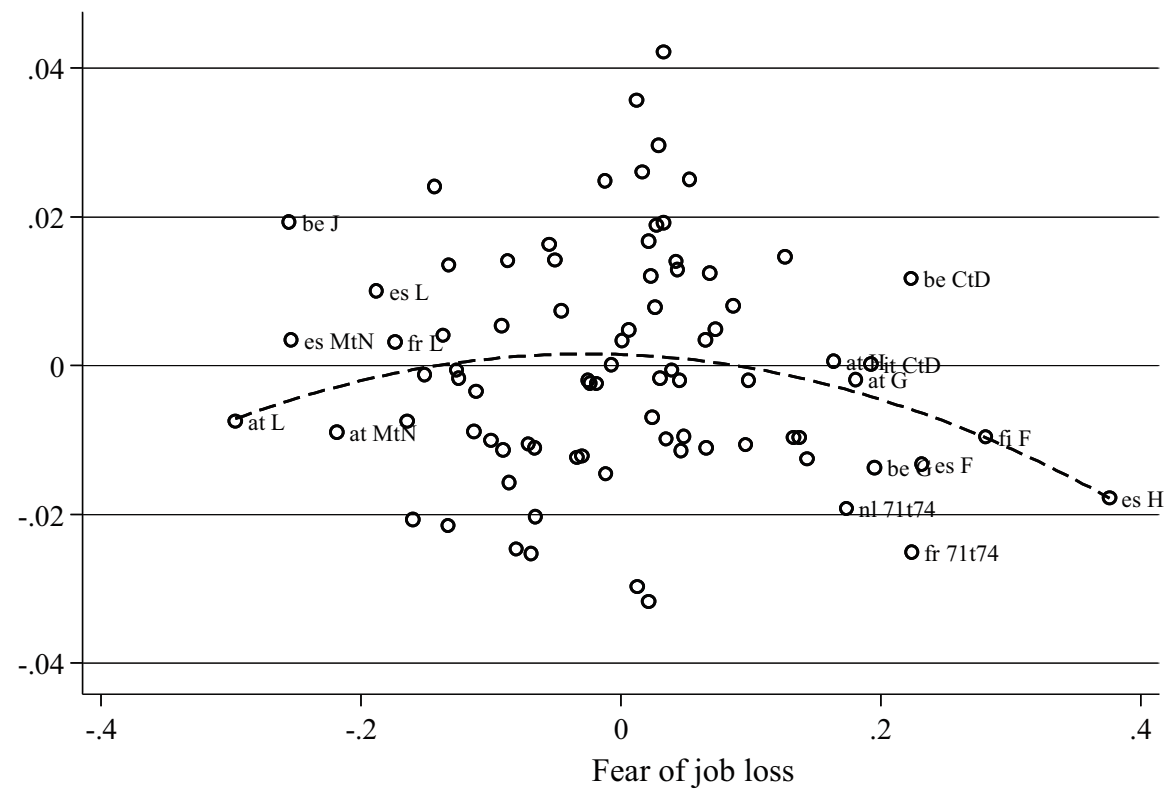

Fig. 4.3 Partial regression plot between fear of job loss and TFP growth—sectors in EU-15 countries

Notes: On sector abbreviations, $\mathrm{CtD}=$ manufacturing; $\mathrm{F}=$ construction; $\mathrm{G}=$ wholesale and retail trade; $\mathrm{H}=$ hotels and restaurants; $\mathrm{J}=$ financial intermediation; $71-74=\mathrm{K} 71-74=$ business activities, excluding real estate activities; $\mathrm{MtN}=$ education and health; $\mathrm{L}=$ public administration. For countries, $\mathrm{be}=$ Belgium; $\mathrm{fr}=$ France; $\mathrm{nl}=$ the Netherlands; $\mathrm{fi}=$ Finland; $\mathrm{es}=$ Spain, it $=$ Italy; at $=$ Austria. 
high levels of fear of job loss include wholesale and retail trade $(\mathrm{G})$ in Austria and Belgium, hotels and restaurants $(\mathrm{H})$ in Spain and Austria, manufacturing (CtD) in Belgium and Italy, construction in Spain and Finland, and business in the Netherlands and France (K71-74). In this instance, the high levels of fear of job loss in the knowledge-intensive production of business activities (K71-74) in the Netherlands and France seem worrying for the competitiveness of their firms.

\section{Econometric Analysis}

When estimating Eq. (4.1) in Sect. 3, a least square dummy variable (LSDV) approach is applied to take into account the interdependence of observations in sectors and countries. ${ }^{2526}$ In addition, to control for potential cross-sectional heteroscedasticity, a robust-VCE estimator has been utilized. ${ }^{27}$ Regressions 1 and 2 depict the relationship between the trust proxies and TFP growth. ${ }^{28}$ Both trust proxies turn out to be insignificant. The results hold no matter which dummies are included in the regressions. ${ }^{29}$

Regressions 3-7 analyze the relationship between fear of job loss and TFP growth. When analyzing all countries in the given sample and controlling for country and industry-specific effects (regression 3), the squared term of the fear of job loss exhibits no significant relationship. Once excluding the country dummy in regression 4, however, the relationship of the squared term becomes significant (at the $90 \%$ level) with a coefficient of -0.04 . As depicted earlier in Fig. 4.2, this curvilinear relationship seems to be strongly driven by the three transition countries, the Czech Republic, Slovenia, and Hungary. As can be observed from Table 4.1 above, in those three countries the levels of fear of job loss are significantly higher in almost all sectors compared with those of EU-15 countries, especially in the Czech Republic (with values close to 0). Given that these three countries act as outliers with respect to the EU-15 country sample, regressions 5-7 focus on the remaining

\footnotetext{
${ }^{25}$ The assumptions on the residuals are met and allow the estimation through LSDV. The residuals are symmetrically distributed around 0 and follow a normal distribution. The underlying graphical results from the rvfplot, qnorm, and pnorm Stata command can be obtained from the author on request.

${ }^{26}$ McMorrow et al. (2010) have also utilized sectoral and country dummies in their analysis.

${ }^{27}$ The Stata robust command is based on the Huber-Sandwich Estimator.

${ }^{28}$ To reduce the degree of multicollinearity, when constructing the squared terms of each respective variable, the underlying variables were first centered. This means that the mean of the variable was subtracted from its real value (see here Kutner et al., 2004, p. 295). It turns out that the correlation between these two variables effectively goes down from 0.92 to 0.57 .

${ }^{29}$ In addition, both proxies turn out to be insignificant when modeling them linearly. The results can be obtained from the author. The insignificant result might also stem from the fact that the proxy used misspecified the concept of trust.
} 
Table 4.2 Organizational trust, fear of job loss, and TFP growth, LSDV estimation

\begin{tabular}{|c|c|c|c|c|c|c|c|}
\hline $\begin{array}{l}\text { Estimation } \\
\text { method }\end{array}$ & \begin{tabular}{|l} 
LSDV, \\
robust
\end{tabular} & $\begin{array}{l}\text { LSDV, } \\
\text { robust }\end{array}$ & $\begin{array}{l}\text { LSDV, } \\
\text { robust }\end{array}$ & $\begin{array}{l}\text { LSDV, } \\
\text { robust }\end{array}$ & $\begin{array}{l}\text { LSDV, } \\
\text { robust }\end{array}$ & $\begin{array}{l}\text { LSDV, } \\
\text { robust }\end{array}$ & $\begin{array}{l}2 \text { SLS, } \\
\text { robust }\end{array}$ \\
\hline $\begin{array}{l}\text { Country } \\
\text { sample }\end{array}$ & All & All & All & All & EU-15 & EU-15 & EU-15 \\
\hline Equation & 1 & 2 & 3 & 4 & 5 & 6 & 7 \\
\hline $\begin{array}{l}\text { Trust } \\
\text { colleagues, } \\
\text { squared }\end{array}$ & $\begin{array}{l}-0.013 \\
(0.024)\end{array}$ & - & $\begin{array}{l}- \\
-\end{array}$ & $\begin{array}{l}- \\
-\end{array}$ & $\begin{array}{l}- \\
-\end{array}$ & - & - \\
\hline $\begin{array}{l}\text { Trust } \\
\text { colleagues, } \\
\text { squared }\end{array}$ & $\begin{array}{l}-0.026 \\
(0.042)\end{array}$ & - & $\begin{array}{l}- \\
-\end{array}$ & $\begin{array}{l}- \\
-\end{array}$ & $\begin{array}{l}- \\
-\end{array}$ & - & - \\
\hline Trust boss & - & $\begin{array}{l}-0.003 \\
(0.027) \\
\end{array}$ & $\begin{array}{l}- \\
-\end{array}$ & $\begin{array}{l}- \\
-\end{array}$ & $\begin{array}{l}- \\
-\end{array}$ & - & - \\
\hline $\begin{array}{l}\text { Trust boss, } \\
\text { squared }\end{array}$ & - & $\begin{array}{l}-0.020 \\
(0.043)\end{array}$ & $\begin{array}{l}- \\
-\end{array}$ & $\begin{array}{l}- \\
-\end{array}$ & $\begin{array}{l}- \\
-\end{array}$ & - & - \\
\hline Fear of job loss & - & - & $\begin{array}{l}0.000 \\
(0.026)\end{array}$ & $\begin{array}{l}0.008 \\
(0.009)\end{array}$ & $\begin{array}{l}-0.031 \\
(0.019)\end{array}$ & $\begin{array}{l}-0.001 \\
(0.013)\end{array}$ & $\begin{array}{l}-0.005 \\
(0.020)\end{array}$ \\
\hline $\begin{array}{l}\text { Fear of job } \\
\text { loss, squared }\end{array}$ & - & - & $\begin{array}{l}0.006 \\
(0.035)\end{array}$ & $\begin{array}{l}-0.040 * \\
(0.024)\end{array}$ & $\begin{array}{l}-0.066 \\
(0.046)\end{array}$ & $\begin{array}{l}-0.111 * * \\
(0.045)\end{array}$ & $\begin{array}{l}-0.138^{*} \\
(0.082)\end{array}$ \\
\hline Catch-up term ${ }^{\mathrm{a}}$ & Yes & Yes & Yes & Yes & Yes & Yes & Yes \\
\hline $\begin{array}{l}\text { Growth at the } \\
\text { frontier }^{\mathrm{a}}\end{array}$ & No & No & No & No & No & Yes & Yes \\
\hline $\begin{array}{l}\text { Country } \\
\text { dummies }\end{array}$ & Yes & Yes & Yes & No & Yes & Yes & Yes \\
\hline $\begin{array}{l}\text { Industry } \\
\text { dummies }\end{array}$ & Yes & Yes & Yes & Yes & Yes & No & No \\
\hline $\begin{array}{l}\text { No. of } \\
\text { observations }\end{array}$ & 103 & 103 & 100 & 100 & 82 & 82 & 82 \\
\hline $\begin{array}{l}\text { No. of } \\
\text { countries }\end{array}$ & 15 & 15 & 15 & 15 & 12 & 12 & 12 \\
\hline R-square & 0.57 & 0.56 & 0.57 & 0.42 & 0.57 & 0.35 & 0.35 \\
\hline
\end{tabular}

Notes: Organizational trust and fear of job loss variables are centered to reduce the degree of multicollinearity (Kutner et al., 2004, pp. 295-300).

$* * * \mathrm{p}<0.01, * * \mathrm{p}<0.05, * \mathrm{p}<0.1$.

${ }^{\mathrm{a}}$ For the EU-15 sample, these variables differ slightly from the larger sample, as technological leaders might change. Instrumental variables in regression 7 include the type of working contract and size of organization. The numbers in parentheses are robust standard errors.

12 countries of the EU-15 country sample. When controlling for country and industry effects in regression 5, no significant relationship between fear of job loss and TFP growth appears in the EU-15 country sample. However, as this contribution is foremost interested in a cross-sectoral approach rather than a cross-country approach, it seems reasonable to exclude the industry dummy in order to obtain the full variance of the industrial sector observations. When excluding the industry dummy in regression 6, a significant (at the 95\% level) negative effect (with a coefficient of -0.111) between the squared term of fear of job loss and TFP growth appears. The specific pattern of this curvilinear relationship is shown in detail in Fig. 4.3. The coefficient of fear of job loss in regression 6 is -0.001 for the linear 
term and -0.111 for the squared term. With a coefficient of this size, the optimal level of fear of job loss is $-64 \%$ in the EU-15 country sample. ${ }^{30}$ Thus, from a productivity point of view, the optimal proportions of fear of job loss at the aggregated level should equal approximately four-fifths (82\%) of employees who do not fear job loss and one-fifth (18\%) who do. With a current mean of $-63 \%$, aggregate fear of job loss is at its optimal point. Comparing the optimal level of fear of job loss with the average sectoral levels in Table 4.1, it becomes apparent that there are sectors with fear of job loss levels that are too high, optimal, and too low. The sectors with fear of job loss levels that are excessively high are hotels and restaurants $(\mathrm{H})$ (24.4), construction $(\mathrm{F})(10.3)$, and business activities (K) (9.7). The sectors with an optimal fear of job loss level are wholesale and retail trade (G) (5.8), manufacturing and mining (CtD) (5.4), and transport and communication (I) (4.7). The sectors that on average have fear of job loss levels that are too low are financial intermediation (J) (-11.2), public administration (L) (-14.4), and education and health $(\mathrm{MtN})(-14.6)$. Analyzing these results from a country perspective, one could conclude that employees report too much fear of job loss in Germany (17.7) and Spain (15.3), an optimal level in Austria (2.1), Belgium (-1.8), and Italy (-0.2), and too little in the UK $(-14)$ and Denmark $(-15.7)$.

When running growth regressions, such as in eq. (4.1) and regression 6, one must be aware of the possibility that the left-hand side and the right-hand side variables will affect one another. More specifically, the independent variable fear of job loss might be endogenous, affected by a common event ,such as an economic shock, or stand in a bi-directional relationship with TFP growth; thus, lower levels of TFP growth might, for example, influence an agent's fear of job loss. As there is no information on fear of job loss for the period $t-1$, the only possible solution is to retrieve valid external instruments ${ }^{31}$ for fear of job loss. To address the possibility of endogeneity, a two-stage least squares (2SLS) estimation has been applied in regression 7. The set of instruments utilized include among others the firm size (medium and large) and type of working contract (indefinite and fixed). The

\footnotetext{
${ }^{30}$ The calculation to determine the optimal level of fear of job loss in an EU-15 country sample has been derived in the following manner: first, one differentiates Eq. (4.1) with respect to $\mathrm{OTF}_{i, j, t}$. With $\beta_{3}=-0.001$ and $\beta_{4}=-0.111$ one arrives at $\frac{\partial \widehat{T F P}_{i, j, t}}{\partial \operatorname{OTF}_{i, t, t}}=-0.001-0.222 \mathrm{OTF}_{i, j, t}$. Second, to determine the optimal $\mathrm{OTF}_{i, j, t}$ value, one solves the following equation: $-0.001-0.222 \mathrm{OTF}_{i, j, t}=0$ with respect to $\mathrm{OTF}_{i, j, t}$ and we obtain $\mathrm{OTF}_{i, j, t}=0.001 /-0.222=-0.0045$. As this value is still centered, it still has to be demeaned by adding the mean value of -0.6294 to the optimal point of -0.0045 to obtain a demeaned optimal point of $-0.6339 \approx-0.63$. For reasons of comparability with Table 4.1 , this value is multiplied by 100 to derive an optimal value of $-64 \%$. Utilizing the same methodology for regression 4 , the optimal level of fear of job loss is then $-45 \%$.

${ }^{31}$ In the context of curvilinear relationships (as depicted in regression 6), Woolridge (2002, pp. 230-237) advises the direct application of the 2SLS method to both endogenous regressors (the linear and quadratic effect) with the supplementary nonlinear transformations (quadratic terms) of exogenous variables appearing somewhere in the system. A second option is to predict the linear term with the exogenous variables and to square this prediction. Subsequently, the predicted $\left(\widehat{y}_{i}\right)^{2}$ is then added to the instrumental variables regression. Regression 7 depicts the coefficient for the linear and squared term of fear of job loss when utilizing the second option.
} 
underlying specification tests show that the instrument set is valid ${ }^{32}$ and relevant. $^{33}$ Utilizing this set of instruments yields a significant coefficient for the squared term at the $90 \%$ level. The size of the coefficient becomes slightly smaller with a coefficient of $-0.005 /-0.138$ and an optimal point of fear of job loss of $-65 \%$.

\subsection{Sensitivity of Results}

To control whether the empirical result between fear of job loss and TFP growth in regression 6 in Table 4.2 can be considered robust, Table 4.3 presents the results of a sensitivity analysis on the coefficient of fear of job loss in regression 6 in Table 4.2. The first row, under the heading "Baseline Regression" thus depicts the coefficient of regression 6 .

The second row excludes obvious outliers that might drive the curvilinear relationship as identified in Fig. 4.3. After excluding Spain's hotel and restaurant sector (es $\mathrm{H}$ ), the coefficient remains significant at the $95 \%$ level. After additionally excluding Austria's public administration and defense sector (at L) in row 3, the coefficient remains significant at the $95 \%$ level.

Rows 4-7 analyze the robustness among the various sectors. Figure 4.3 has already highlighted that cases from the public sector seem to be more oriented towards the left-hand side effect of the curvilinear relationship (positive relationship) and those from the service and manufacturing sectors towards the right-hand side (negative relationship). With this observation taken for granted, rows 4-7 differentiate specific sectoral clusters by modeling them in a linear relationship. When analyzing the service $(\mathrm{GtK})$ and manufacturing $(\mathrm{C}-\mathrm{F})$ sectors in rows 4 and 5, one detects a non-significant negative relationship (although for the service sector the $90 \%$ level of significance is only slightly missed). As each of the two sectors only has a small number of observations, row 6 pools the observations of the service and manufacturing sectors into a non-farm market sector classification $(\mathrm{C}-\mathrm{K})$. When analyzing the 59 observations from the non-farm market sector $(\mathrm{C}-\mathrm{K})$, a negative linear relationship (at the $95 \%$ level) is notable. This result gives some initial empirical evidence of the assumption that the left-hand side effect of the curvilinear relationship (positive relationship) is driven by the public sector while the right-hand side effect (negative relationship) is driven by the non-farm market sector. The obtained $\beta_{3}$-coefficient of -0.06 should be interpreted in the following manner: on average a sector with a fear of job loss level that is $10 \%$ higher is associated with $0.6 \%$ lower TFP growth. In accordance with this argument, when analyzing the

\footnotetext{
${ }^{32}$ An overidentification test (Hansen $\mathrm{J}$ statistic) of the validity of the instruments was automatically performed within the utilized ivreg2 Stata command (Baum et al., 2010). With a $\chi(3)$ value of 3.67, the rejection of the null hypothesis fails. This indicates that the instruments used are valid.

${ }^{33}$ An underidentification test (Kleibergen-Paap rk LM statistic) was automatically performed within the utilized ivreg2 Stata command (Baum et al., 2010). With a $\chi(4)$ value of 20.3, the rejection of the null hypothesis fails. This indicates that the instruments used are relevant.
} 
Table 4.3 Fear of job loss and TFP growth—sensitivity analysis

\begin{tabular}{|c|c|c|c|c|c|}
\hline Row & Specification change & $\begin{array}{l}\text { Fear of job loss/fear of } \\
\text { job loss squared }\end{array}$ & $\begin{array}{l}\text { Standard } \\
\text { error }\end{array}$ & $\begin{array}{l}\text { No. of } \\
\text { observations }\end{array}$ & R-squared \\
\hline \multicolumn{6}{|c|}{ Baseline regression } \\
\hline 1 & No change & $-0.001 /-0.111 * *$ & \begin{tabular}{|l}
$(0.013) /$ \\
$(0.045)$
\end{tabular} & 82 & 0.35 \\
\hline \multicolumn{6}{|c|}{ Outliers } \\
\hline 2 & Spain sector $\mathrm{H}$ & $-0.003 /-0.150^{* *}$ & $\begin{array}{l}(0.01) / \\
(0.06)\end{array}$ & 81 & 0.34 \\
\hline 3 & $\begin{array}{l}\text { Austria sector } \mathrm{L} \text { and } \\
\text { Spain sector } \mathrm{H}\end{array}$ & $-0.003 /-0.150 * *$ & $\begin{array}{l}(0.01) / \\
(0.07)\end{array}$ & 80 & 0.34 \\
\hline \multicolumn{6}{|c|}{ Restructuring—different sectors } \\
\hline 4 & Service sectors G-K & -0.05 & $(0.03)$ & 40 & 0.47 \\
\hline 5 & Manufacturing sector & -0.03 & $(0.08)$ & 19 & 0.89 \\
\hline 6 & $\begin{array}{l}\text { Nonfarm business } \\
\text { sector C-K }\end{array}$ & $-0.06^{* *}$ & $(0.02)$ & 59 & 0.45 \\
\hline 7 & Public sector & 0.03 & $(0.02)$ & 23 & 0.83 \\
\hline \multicolumn{6}{|c|}{ Control and policy variables $-L R$} \\
\hline 8 & R\&D intensity & $-0.04 *$ & $(0.03)$ & 46 & 0.68 \\
\hline 9 & $\begin{array}{l}\text { Employment } \\
\text { protection }\end{array}$ & $-0.06 * *$ & $(0.02)$ & 59 & 0.46 \\
\hline \multicolumn{6}{|c|}{ Control and policy variables $-C L R$} \\
\hline 10 & $\begin{array}{l}\text { Product market } \\
\text { regulation }\end{array}$ & $0.005 /-0.12 * * *$ & $\begin{array}{l}(0.01) / \\
(0.04)\end{array}$ & 82 & 0.37 \\
\hline 11 & $\begin{array}{l}\text { Firm-specific human } \\
\text { capital }\end{array}$ & $-0.02 /-0.07 * *$ & $\begin{array}{l}(0.01) / \\
(0.04)\end{array}$ & 71 & 0.54 \\
\hline
\end{tabular}

Notes: On abbreviations, $\mathrm{LR}=$ linear relationship and CLR $=$ curvilinear relationship. The fear of job loss variable is centered to reduce the degree of multicollinearity (Kutner et al., 2004, pp. 295300). All regressions include country dummies; numbers in parentheses are robust standard errors. $* * * \mathrm{p}<0.01, * * \mathrm{p}<0.05, * \mathrm{p}<0.1$.

public sectors (L-N) in row 7, one detects a positive but insignificant relationship (which might stem from the small sample size).

To control for the effect of potential control and policy variables, rows 8-11 include R\&D (McMorrow et al., 2010), firm-specific human capital, labor market regulation (Nicoletti \& Scarpetta, 2003; Timmer et al., 2010), and product market regulation (McMorrow et al., 2010; Nicoletti \& Scarpetta, 2003; Timmer et al., 2010). As the variables for R\&D and labor market regulation are only available for the non-farm business sector, the coefficient of the linear relationship as depicted in row 6 is used as the basis of the sensitivity analysis in rows 8 and 9. After including the control variable, the coefficient remains negative and significant at the $90 \%$ and 95\% levels. Rows 10 and 11 control for the inclusion of firm-specific human capital and product market regulation. The significance of the curvilinear relationship is not altered. 


\subsection{How Do these Results Fit in with Other Existing Empirical Results?}

To the author's knowledge, this is the first empirical analysis of the relationship between organizational trust, fear of job loss and TFP growth at a sectoral level. This section discusses the empirical evidence, using different research designs for interpreting the results presented above.

The non-significant empirical results between organizational trust and economic performance contrast with the positive finding by Frenkel and Orlitzky (2005) that higher workplace trust leads to higher workplace labor productivity. The results also contrast with the negative finding by Langfred (2004), that an excessively high trust level among autonomous, self-managing work teams leads to diminished monitoring activity and lower overall team performance, as well as the finding by Zaheer et al. (1998) of a positive relationship between interorganizational trust and economic performance. Likewise, the empirical results differ from the existing curvilinear evidence between interpersonal trust at the nation-state level (Roth, 2009) and individual level (Butler et al., 2009), and between interorganizational trust (Bidault $\&$ Castello, 2009) and economic performance. A final interpretation of the results, however, should be treated with caution, as the invalidity of the proxy may be affecting the empirical results.

The significant curvilinear relationship between job insecurity and economic performance may be related to empirical results by Brockner et al. (1992), who find a curvilinear relationship between job insecurity and employees' work efforts. The left-hand side of the curvilinear relationship (positive relationship) is in accordance with empirical work by Probst (2002, p. 211), who finds that job insecurity is associated with higher productivity but lower quality output, and by Probst et al. (2007), who find that job insecurity is associated with higher productivity but lower creative problem-solving. The right-hand side of the curvilinear relationship (negative relationship) can be linked to empirical results by Reisel et al. (2007), who report a negative relationship between job insecurity and organizational performance, and by D'Souza et al. (2006), who focus on sickness absence as a key indicator of labor productivity and find a negative relationship between job insecurity and organizational performance. The results are in contrast to the claim by Sverke et al. (2002) who find, when conducting a meta-analysis, that job insecurity and work performance are not significantly related to one another.

\subsection{Objective Forces Driving Job Insecurity at the Individual Level}

For a policy-relevant conclusion, one might turn to the question of which objective factors potentially shaped by policy-makers are the driving forces behind employees' fears of job loss. To answer this question, the results of a generalized 
Table 4.4 Type of work contract and employees' fear of job loss, EU-15, 2005

\begin{tabular}{l|l|l}
\hline & \multicolumn{2}{|l}{ Marginal effects } \\
\hline & Strongly disagree & Strongly agree \\
\hline \multirow{2}{*}{ Indefinite contract } & $0.12^{* * *}$ & $-0.03^{* * *}$ \\
\cline { 2 - 3 } & $(0.02)$ & $(0.01)$ \\
\hline \multirow{2}{*}{ Fixed contract } & $-0.14^{* * *}$ & $0.07 * * *$ \\
\cline { 2 - 3 } & $(0.03)$ & $(0.02)$ \\
\hline
\end{tabular}

Notes: Estimation by a generalized ordered probit model. The displayed values depict the marginal effects. The control variables include gender, age, size of household, tenure, living with partner, at least one other income in the household, education dummies for ISCED 3-4 and ISCED 5-6, gender of boss, regional unemployment rate, ISCO dummies, country dummies, and sectoral dummies (Table 4.A2). The excluded categories are other contracts, ISCED $0-2$, female, female boss, no other income, and no partner. Similar, but distinct control variables have been used by Campbell et al. (2007). The numbers in parentheses are robust standard errors. The number of observations is 6,774 employees from 12 EU-15 countries. Filters have been utilized as described above. $* * * \mathrm{p}<0.01, * * \mathrm{p}<0.05, * \mathrm{p}<0.1$.

Source: EWCS 2005 (Eurofound, 2005).

ordered probit model ${ }^{34}$ estimating individual data from the EWCS fourth wave (Eurofound, 2005) with a total of 6, 744 employee observations (drawn from 12 of the EU-15 countries) are presented in Table 4.4. Based on the given theoretical and empirical literature (Leana \& van Buren III, 2000, p. 230; Eurofound, 2010b; Campbell et al., 2007, p. 552), the analysis focuses primarily on one objective factor regarded by the author as realistically influenced by policy-makers: the impact of the type of working contract on an employee's fear of job loss. ${ }^{35}$ Table 4.4 shows the results (marginal effects) for the two response categories "Strongly disagree" and "Strongly agree" of a generalized ordered probit model with job insecurity as the dependent variable, and indefinite and fixed working contracts as independent variables (under the control of various, theoretically important variables). When interpreting the marginal effects of the two response categories "Strongly agree" and "Strongly disagree," it can be concluded that concerning indefinite contracts, in all sectors the probability of responding "Strongly disagree" is around 12\% higher for employees who have an indefinite contract and $14 \%$ lower for employees who have a fixed contract. Concerning fixed contracts, in all sectors, the probability of

\footnotetext{
${ }^{34}$ Because the measurement of job insecurity in the EWCS of 2005 (Eurofound, 2005) is on a fivepoint scale, an ordered probit analysis has been utilized for this purpose. As the underlying assumptions for estimating a proportional odds model are violated, the likelihood-ratio test of the equality of coefficients clearly rejects the null hypothesis of no violation, a generalized ordered probit model is estimated in which coefficients are allowed to vary over outcome categories (Boes, 2006).

${ }^{35}$ In contrast to Campbell et al. (2007), who find that $77 \%$ of workers who have a high fear of job loss have indefinite contracts, among the given population of 6,744 employees within the fourth wave of the EWCS (Eurofound, 2005), only $57 \%$ of the workers who have a high fear of job loss (agree + strongly agree) have indefinite contracts.
} 
responding "Strongly agree" is around 7\% higher for employees who have a fixed contract and $3 \%$ lower who have an indefinite contract.

\section{Conclusion}

This contribution has analyzed the relationship between organizational trust, fear of job loss, and TFP growth at a sectoral level in a European country sample. Six empirical conclusions are noteworthy.

First, there is no significant relationship between organizational trust and TFP growth at the sectoral level. This finding is in contrast to most other findings in the general literature on trust and economic performance. As the non-significant result might, however, be due to the invalidity of the proxy used, this result should be interpreted with caution. Taking the theoretical literature and the most recent empirical work on the relationship between trust and economic performance seriously, a valid measure of trust should most likely yield a curvilinear relationship between trust and growth.

Second, there is a curvilinear relationship between fear of losing one's job and TFP growth at the sectoral level in a European country sample of 100 observations consisting of 15 EU-27 countries. This curvilinear relationship is driven by the three transition countries, the Czech Republic, Slovenia, and Hungary, indicating that in all three countries fear of job loss levels are above optimality with respect to TFP growth.

Third, given an EU-15 country sample with a total of 82 observations, a curvilinear relationship is detected. This curvilinear relationship proves to be robust 1) when controlling for potential endogeneity, 2) excluding outliers, and 3) including relevant policy variables. The curvilinear relationship is driven by the sectoral variance within the given sample. The sectors with levels of fear of job loss that are excessively high are hotels and restaurants, construction, and business activities. The sectors with an optimal level of fear of job loss are wholesale and retail trade, manufacturing and mining, and transport and communication. The sectors that on average have fear of job loss levels that are too low are financial intermediation, public administration, and education and health.

Fourth, when analyzing the curvilinear relationship between fear of job loss and TFP growth in the EU-15 country sample from a sectoral perspective, the individual sectors exhibiting levels of fear of job loss that are too low are public administration in Austria, Spain, and France, education and health in Austria and Spain, and financial intermediation in Belgium. Those exhibiting fear of job loss levels that are too high are wholesale and retail trade in Austria and Belgium, hotels and restaurants in Spain and Austria, manufacturing in Belgium and Italy, construction in Spain and Finland, and business in the Netherlands and France.

Fifth, when analyzing the curvilinear relationship between fear of job loss and TFP growth within the EU-15 country sample from a country perspective, employees exhibit excessive fear of job loss across the sectors in Germany and Spain, an optimal level in Austria, Belgium, and Italy, and too little in the UK and Denmark. 
Sixth, on an individual basis, an objective factor that is associated with fear of job loss is the type of contract an employee possesses. As expected, employees with indefinite contracts are significantly less afraid of losing their jobs than those with fixed contracts.

The following four policy conclusions can be drawn. The first two are general policy conclusions and the latter two seek to improve lagging TFP growth.

First, to address ethical concerns, Eurofound should consider incorporating a valid measure of organizational trust in the next design of the EWCS (most likely to be conducted in 2015). The concept of organizational trust is theoretically too important not to be validly measured in publicly available surveys. ${ }^{36}$

Second, as job insecurity theoretically and empirically seems to have a significant and curvilinear relationship with TFP growth, academic research in economics that interlinks such psychological concepts as trust to economic performance should also extend awareness of the importance of the concept of fear (of job loss). In addition, the concept of the "dark side of trust" (Gargiulo \& Ertug, 2006) has been neglected by current academic research focusing on the relationship between trust and economic performance. Being aware of this "dark side of trust", academic research should incorporate models of trust and economic performance in a curvilinear manner.

Third, from a policy point of view, most sectoral fear of job loss levels in the three transition countries are well above the optimal degree of fear of job loss with respect to TFP growth. In all three countries, employment relations seem to be too deregulated and liberalized with respect to the high levels of job insecurity found in most sectors. From a fear of job loss perspective, these countries should implement regulations enhancing job security. Such regulations should be implemented by governmental actors in consultation with labor unions and employer organizations.

Fourth, from a policy point of view, there are some sectors in the EU-15 in which employment relations need to be further deregulated and liberalized to improve the EU's productivity performance, especially public administration, health and education, and financial intermediation. In other sectors, notably construction on the manufacturing side, and hotels and restaurants and business services on the services side, fear of job loss has already reached levels that are counterproductive to Europe's productivity performance. Here, foremost, the excessive levels of fear of job loss in the business services seem particularly worrying, as this sector is deeply engaged in knowledge production-a key asset for the future competitiveness of European economies. In these sectors, liberalization has already been taken too far, triggering growth-hampering effects, as discussed in the theoretical part of this contribution. These sectors should be regulated again towards more job security.

\footnotetext{
${ }^{36}$ Private consultancy firms that are aware of the importance of trust do measure it, but their results are not made publicly available to academic researchers.
} 


\section{Appendix}

Table 4.A1 Summary statistics for the aggregate data analysis

\begin{tabular}{l|l|l|l|l|l}
\hline Variable & Observations & Mean & Std. Dev. & Min. & Max. \\
\hline TFP growth & 165 & 0.007 & 0.023 & -0.091 & 0.074 \\
\hline Catch-up term & 165 & -0.63 & 0.58 & -4.79 & 0 \\
\hline Growth at the frontier & 165 & 0.009 & 0.027 & -0.029 & 0.07 \\
\hline Trust colleagues & 103 & 0.69 & 0.19 & 0.075 & 0.96 \\
\hline Trust boss & 103 & 0.52 & 0.23 & -0.11 & 0.83 \\
\hline Fear of job loss & 100 & -0.55 & 0.25 & -0.95 & 0.30 \\
\hline Contract fixed & 82 & 0.11 & 0.072 & 0.0 & 0.42 \\
\hline Indefinite contract & 82 & 0.77 & 0.14 & 0.25 & 0.98 \\
\hline Medium-size firm & 82 & 0.45 & 0.10 & 0.22 & 0.69 \\
\hline Large-size firm & 82 & 0.30 & 0.16 & 0.02 & 0.73 \\
\hline R\&D intensity (in \%) & 46 & 1.92 & 3.11 & 0 & 12.95 \\
\hline Employment protection & 59 & 2.30 & 1.28 & 0.46 & 5.61 \\
\hline Product market regulation & 82 & 0.15 & 0.13 & 0.019 & 0.43 \\
\hline Firm-specific human capital & 71 & 0.11 & 0.079 & 0.018 & 0.35 \\
\hline & & & & &
\end{tabular}

Table 4.A2 Summary statistics for the individual analysis

\begin{tabular}{l|l|l|l|l|l}
\hline Variable & Observations & Mean & Std. Dev. & Min. & Max. \\
\hline Job insecurity & 6774 & 1.90 & 1.17 & 1 & 5 \\
\hline Male & 6774 & 0.47 & 0.50 & 0 & 1 \\
\hline Age & 6774 & 40.6 & 11.6 & 15 & 72 \\
\hline Tenure & 6774 & 20.6 & 12.5 & 0 & 64 \\
\hline Size of household & 6774 & 2.8 & 1.4 & 1 & 13 \\
\hline Indefinite contract & 6774 & 0.79 & 0.41 & 0 & 1 \\
\hline Fixed contract & 6774 & 0.11 & 0.31 & 0 & 1 \\
\hline Living with a partner & 6774 & 0.64 & 0.49 & 0 & 4 \\
\hline At least one other income & 6774 & 0.61 & 0.49 & 0 & 1 \\
\hline ISCED 3-4 & 6774 & 0.50 & 0.50 & 0 & 1 \\
\hline ISCED 5-6 & 6774 & 0.30 & 0.46 & 0 & 1 \\
\hline Male boss & 6774 & 0.68 & 0.47 & 0 & 1 \\
\hline Regional unemployment rate & 6774 & 7.12 & 3.35 & 2.6 & 21.3 \\
\hline
\end{tabular}




\section{References}

Ashford, S. J., Lee, C., \& Bobko, P. (1989). Content, causes and consequences of job insecurity: A theory-based measure and substantive test. Academy of Management Journal, 32(4), 803-829.

Ashkanasy, N. M., \& Nicholson, G. J. (2003). Climate of fear in organisational settings: Construct definition, measurement and a test of theory. Australian Journal of Psychology, 55(1), 24-29.

Bidault, F., \& Castello, A. (2009). Trust and creativity: understanding the role of trust in creativityoriented joint developments. R\&D Management, 39(3), 259-270.

Baum, C. F., Schaffer, M. E., \& Stillman, S. (2010). IVREG2: Stata module for extended instrumental variables/2SLS, GMM and AC/HAC, LIML and k-class regression. Boston College. http://ideas.repec.org/c/boc/bocode/s425401.html

Black, S. E., \& Lynch, L. M. (2005). Measuring organizational capital in the new economy. In C. Corrado, J. Haltiwanger, \& D. Sichel (Eds.), Measuring capital in the new economy (pp. 205-236). University of Chicago Press.

Blanchflower, D., \& Oswald, A.J. (1999). Well-Being, Insecurity and the Decline of American Job Satisfaction. Mimeo, 22 July.

Blanchflower, D. (1991). Fear, unemployment and pay flexibility. Economic Journal, 101(406), 483-496.

Bloom, N., \& van Reenen, J. (2007). Measuring and explaining management practices across firms and nations. Quarterly Journal of Economics, 122(4), 1351-1408.

Boes, S. (2006). GOBROBIT: Stata module to estimate generalized ordered probit models. http:// fmwww.bc.edu/repec/bocode/g/goprobit.ado.

Brockner, J., Grover, S., Reed, T. F., \& Dewitt, R. L. (1992). Layoffs, job insecurity, and survivors' work effort: evidence of an inverted-U relationship. Academy of Management Journal, 35(2), 413-425.

Butler, J., Guilano, P., \& Guiso, L. (2009). The right amount of trust, EUI working papers - ECO 2009/33. Department of Economics, European University Institute.

Campbell, D., Carruth, A., Dickerson, A., \& Green, F. (2007). Job insecurity and wages. Economic Journal, 117(518), 544-566.

Corrado, C., Hulten, C., \& Sichel, D. (2005). Measuring capital and technology: An expanded framework. In C. Corrado, J. Haltiwanger, \& D. Sichel (Eds.), Measuring capital in the new economy (pp. 11-45). University of Chicago Press.

Corrado, C., Hulten, C., \& Sichel, D. (2009). Intangible capital and economic growth in the US. Review of Income and Wealth, 55(3), 661-685.

D’Souza, R. M., Strazdins, L., Brom, D. H., Rodgers, B., \& Berry, H. L. (2006). Work demand, job insecurity and sickness absence from work: How productive is the new, flexible labour force? Australian and New Zealand Journal of Public Health, 30(3), 205-212.

De Witte, H. (2005). Job insecurity: Review of international literature on definitions, prevalence, antecedents and consequences. The Journal of Individual Psychology, 31(4), 1-6.

Dirks, K. T., \& Ferrin, D. L. (2001). The role of trust in organizational settings. Organization Science, 12(4), 450-467.

Dirks, K. T., \& Skarlicki, D. P. (2004). Trust in Leaders: Existing Research and Emerging Issues. In R. M. Kramer \& K. S. Cook (Eds.), Trust and distrust in organizations - dilemmas and approaches. Russell Sage Foundation.

Elias, N. (1980). Über den Prozeß der Zivilisation - Soziogenetische und psychogenetische Untersuchungen. Zweiter Band. Wandlungen der Gesellschaft - Entwurf zu einer Theorie der Zivilisation. Suhrkamp.

Eurofound (2005). European working conditions survey, 2005 [computer file]. UK Data Archive [distributor], SN: 5639. Colchester, Essex, May 2007. https://doi.org/10.5255/UKDA-SN5639-1.

Eurofound (2007). Quality report of the 4th European working condition survey. Eurofound. 
Eurofound. (2010a). European Working Conditions Survey, 2010 [computer file]. UK Data Archive [distributor], SN: 6971. Colchester, Essex, February 2012. https://doi.org/10.5255/UKDA-SN6971-1.

Eurofound. (2010b). Changes over time - First findings from the fifth European Working Condition Survey. Eurofound. http://www.eurofound.europa.eu/pubdocs/2010/74/en/3/EF1074EN.pdf

Frenkel, S., \& Orlitzky, M. (2005). Organizational trustworthiness and workplace labour productivity: Testing a new theory. Asia Pacific Journal of Human Resources, 43(1), 34-51.

Fukuyama, F. (1996). Trust: The social virtues and the creation of prosperity. Free Press.

Gargiulo, M., \& Ertug, G. (2006). The dark side of trust. In R. Bachmann \& A. Zaheer (Eds.), Handbook of trust research. Edward Elgar.

Greenhalg, L., \& Rosenblatt, Z. (2010). Evolution of research on job insecurity. International Studies of Management \& Organization, 40(1), 6-19.

Hardin, R. (2006). Trust. Polity Press.

Harisalo, R., \& Stenvall, J. (2004). Trust as capital: The foundation of management. In M. Huotari \& M. Iivonen (Eds.), Trust in knowledge management and systems in organizations. Idea Group Publishing.

Heliwell, J. F., \& Huang, H. (2011). Well-being and trust in the workplace. Journal of Happiness Studies, 12(5), 747-767.

Heliwell, J. F. (2006). Well-Being, social capital and public policy: What's new? Economic Journal, 166, C34-C55.

Heliwell, J. F., Huang, H., \& Putnam, R. D. (2009). How's the job? Are trust and social capital neglected workplace investments? In V. O. Bartkus \& J. H. Davis (Eds.), Social capital: Reaching out, reaching in (pp. 87-144). Edward Elgar Publishing.

INDICSER. (2013). Indicators for evaluating international performance in service sectors, project coordinator. Birmingham Business School, University of Birmingham. https://cordis.europa. eu/project/id/244709/de

Inklaar, R., \& Timmer, M. P. (2008). GGDC productivity level database: International comparisons of output, inputs and productivity at the industry level, groningen growth and development centre research memorandum GD-104. University of Groningen.

Knack, S., \& Keefer, P. (1997). Does social capital have an economic payoff-A cross-country comparison. Quarterly Journal of Economics, 112, 1251-1288.

Kutner, M. H., Nachtsheim, C. J., Neter, J., \& Li, W. (2004). Applied linear statistical models. McGraw-Hill.

Langfred, C. W. (2004). Too much of a good thing? Negative effects of high trust and individual autonomy in self-managing teams. Academy of Management Journal, 47(3), 385-399.

Leana, C., \& van Buren, H. J., III. (1999). Organizational social capital and employment practices. Academy of Management Review, 24(3), 538-555.

Leana, C., \& van Buren, H. J., III. (2000). Eroding organizational social capital among US firms: The price of job instability. In R. Burke \& C. Cooper (Eds.), The organization in crisis Downsizing, restructuring and privatization.

Lev, B., \& Radhakrishnan, S. (2005). The valuation of organizational capital. In C. Corrado, J. Haltiwanger, \& D. Sichel (Eds.), Measuring capital in the new economy (pp. 73-110). University of Chicago Press.

Marcuse, H. (1998). Der eindimensionale Mensch - Studien zur Ideologie der fortgeschrittenen Industriegesellschaft. München.

Marks, L. M. (2003). Charging back up the hill: Workplace recovery after mergers, acquisition and downsizing. Jossey-Bass.

Mayer, R. C., Davis, J., \& Schoorman, D. (1995). An integrative model of organizational trust. Academy of Management Review, 20(3), 709-734.

McMorrow, K., Röger, W., \& Turrini, A. (2010). Determinants of TFP growth: A closer look at industries driving the EU-US gap. Structural Change and Economic Dynamics, 21(3), $165-180$. 
Murray, M. P. (2006). Avoiding invalid instruments and coping with weak instruments. Journal of Economic Perspectives, 20(4), 120-126.

Nahapiet, J., \& Goshal, S. (1998). Social capital, intellectual capital and the organizational advantage. Academy of Management Review, 23(2), 242-266.

Nicoletti, G., \& Scarpetta, S. (2003). Regulation, productivity and growth: OECD evidence. Economic Policy, 18(36), 9-72.

Patterson, M., Warr, P., \& West, M. (2004). Organizational climate and company productivity: The role of employee affect and employee level. Journal of Occupational and Organizational Psychology, 77(2), 193-216.

Probst, T. (2002). Layoffs and tradeoffs: Production, quality, and safety demands under the threat of job loss. Journal of Occupational Health Psychology, 7(3), 211-220.

Probst, T., Stewart, S. M., Gruys, M. L., \& Tierney, B. W. (2007). Productivity, counter productivity and creativity: The ups and downs of job insecurity. Journal of Occupational and Organizational Psychology, 80(3), 479-497.

Putnam, R. D. (2000). Bowling alone: The collapse and revival of American community. Simon \& Schuster.

Reisel, W. D., Chia, S.-L., Maloles, C. M., III, \& Slocum, J. W., Jr. (2007). The effects of job insecurity on satisfaction and perceived organizational performance. Journal of Leadership \& Organizational Studies, 14(2), 106-116.

Renzl, B. (2008). Trust in management and knowledge sharing: The mediating effects of fear and knowledge documentation. Omega, 36(2), 206-220.

Roth, F. (2009). Does too much trust hamper economic growth? Kyklos, 62(1), 103-128.

Royuela, V., \& Surinach, J. (2009). Quality in work and aggregate productivity, working paper 2009/01. Research Institute of Applied Economics (IREA).

Saam, M., Cerquera, D., Reitze, G., Inklar, R., O’Mahony, M., Peng, F., Rammer, C., RinconAznar, A., Roth, F., \& Sarbu, M. (2011). First version of indicators on innovation, ICT use and intangibles - Annotations. INDICSER Discussion Paper 4.

Schotter, A. (1996). Worker trust, system vulnerability, and the performance of work groups, economic research report no. 32. New York University.

Staufenbiel, T., \& König, C. J. (2010). A model for the effects of job insecurity on performance, turnover intention, and absenteeism. Journal of Occupational and Organizational Psychology, 83(1), 101-117.

Stock, J. H., \& Watson, M. W. (2007). Introduction to econometrics. Pearson-Addison Wesley.

Sverke, M., Hellgren, J., \& Näswell, K. (2002). No security: A meta-analysis and review of job insecurity and its consequences. Journal of Occupational Health Psychology, 7(3), 242-264.

Timmer, M., van Moergastel, T., Stuivenwold, E., Ypma, G., O’Mahony, M., \& Kangasniemi, M. (2007). EU KLEMS growth and productivity accounts version 1.0 Part I: Methodology. EU KLEMS deliverable.

Timmer, M., Inklaar, R., O’Mahony, M., \& van Ark, B. (2010). Economic growth in Europe. Cambridge University Press.

Van Ark, B., O'Mahony, M., \& Timmer, M. P. (2008). The productivity gap between Europe and the United States: Trends and causes. Journal of Economic Perspectives, 22(1), 25-44.

Whiteley, P. F. (2000). Economic growth and social capital. Political Studies, 48(3), 443-466.

Woolridge, J. M. (2002). Econometric analysis of cross section and panel data. MIT Press.

Zaheer, A., McEvily, B., \& Perrone, V. (1998). Does trust matter? Exploring the effects of interorganizational and interpersonal trust on performance. Organization Science, 9(2), $141-159$. 
Open Access This chapter is licensed under the terms of the Creative Commons AttributionNonCommercial-NoDerivatives 4.0 International License (http://creativecommons.org/licenses/bync-nd/4.0/), which permits any noncommercial use, sharing, distribution and reproduction in any medium or format, as long as you give appropriate credit to the original author(s) and the source, provide a link to the Creative Commons license and indicate if you modified the licensed material. You do not have permission under this license to share adapted material derived from this chapter or parts of it.

The images or other third party material in this chapter are included in the chapter's Creative Commons license, unless indicated otherwise in a credit line to the material. If material is not included in the chapter's Creative Commons license and your intended use is not permitted by statutory regulation or exceeds the permitted use, you will need to obtain permission directly from the copyright holder. 